\title{
Genetic Studies of Flower Color in Anagallis monelli L.
}

\author{
Andrea Quintana ${ }^{1}$ and Rosanna Freyre ${ }^{2,4,5}$ \\ Department of Plant Biology, University of New Hampshire, Durham, \\ NH 03824
}

\author{
Thomas M. Davis ${ }^{3}$ \\ University of New Hampshire, 38 College Road, Spaulding Hall G28, \\ Durham, NH 03824
}

Robert J. Griesbach

Floral and Nursery Plants Research, U.S. Department of Agriculture, Agricultural Research Service, Beltsville, MD, 20705-2350

Additional index words. Myrsinaceae, Primulaceae, anthocyanidins, anthocyanins, pelargonidin, delphinidin, malvidin, genetic segregation ratios

\begin{abstract}
Wild Anagallis monelli exhibits blue or orange flower colors in geographically isolated populations. A new red flower color was developed through breeding, and a three-gene model was proposed for the inheritance of flower color in this species. In this study, blue and orange wild diploid accessions were used as parents to develop six $F_{2}$ populations $(n=19$ to 64$)$. Sexual compatibility between blue and orange wild individuals was low with only $29 \%$ of the hybridizations producing $F_{1}$ individuals. Six of 14 cross combinations between $F_{1}$ siblings produced fruits, and fruiting success ranged from $55 \%$ to $90 \%$. The number of seeds per fruit averaged 14.1 and germination rates for the $F_{2} s$ were low $(16.8 \%$ to $30.7 \%)$. In three of six $F_{2}$ populations obtained, flower color segregation ratios for orange, blue, and red were not significantly different from the expected ratios under a previously proposed three-gene model. White flower color was obtained as a fourth color variant in two of the remaining $F_{2}$ populations. For one of these populations, segregation ratios were not significantly different from expected ratios for an expanded four-gene model. White flowers did not contain anthocyanidins, suggesting that there was a mutation in the early stage of the anthocyanin pathway. Orange flower color was found to be primarily the result of pelargonidin, blue to malvidin, and red to delphinidin. These three pigments may be present simultaneously, and their ratios play a significant role in determining flower color. Other factors such as copigments, metal ions, or a different molecular conformation of the anthocyanin could also be involved in flower color determination.
\end{abstract}

Anagallis monelli is an ornamental annual used for hanging baskets and as a bedding plant because of its very bright and unusual flower colors. This genus currently belongs to the Primulaceae, although recent studies

Received for publication 7 Dec. 2006. Accepted for publication 9 Sept. 2007.

This is Scientific Contribution Number 2305 from the New Hampshire Agricultural Experiment Station. This study was also partly supported by a 2004-2005 grant from The Fred C. Gloeckner Foundation, Inc.

We thank Dr. Paul Fisher for helpful discussions and revisions of early versions of the manuscript. We also thank Dr. Salvador Talavera, Universidad de Sevilla, Spain, and Dr. Francesco Giunta, Università di Sassari, Italy, for their help with obtaining plant material.

${ }^{1}$ MS graduate.

${ }^{2}$ Research Assistant Professor.

${ }^{3}$ Professor.

${ }^{4}$ Current address: University of Florida, Department of Environmental Horticulture, P.O. Box 110670, Gainesville, FL 32611.

${ }^{5}$ To whom reprint requests should be addressed; e-mail rfreyre@ufl.edu based on three chloroplast genes and morphology locate it in the Myrsinaceae (Källersjö et al., 2000). Genetic information about $A$. monelli is scarce, but it is known to exhibit gametophytic self-incompatibility (Gibbs and Talavera, 2001; Talavera et al., 2001), and sampling of several wild populations detected only diploid $(2 n=2 x=20)$ plants (Šveřepová, 1972; Talavera et al., 1997; Valdés, 1970).

Wild individuals of $A$. monelli are native to the Mediterranean region and have small flowers, which are either blue or orange. Populations with these two flower colors are geographically isolated; plants with blue flowers are found in southern Spain, whereas plants with orange flowers are found in southern Italy and Morocco (Talavera, personal communication). Until recently, blue and orange were the only flower colors available in commercial cultivars Skylover Blue and Sunrise, respectively. Since 2002, the Ornamental Breeding program at the University of New Hampshire (UNH) has released additional commercial cultivars of Anagallis in the 'Wildcat'TM series with blue, orange, dark orange, and red flower colors.
Genes involved in the anthocyanin pathway that are responsible for flower color variation have been widely studied, mostly in Petunia and Antirrhinum majus (Brouillard, 1988; Gerats et al., 1982; Holton and Cornish, 1995). In Anagallis, Harborne (1968) detected the flavonols quercetin and kaempferol in flowers of $A$. arvensis and $A$. linifolia; and 3- and 3,5-glycosides of malvidin, delphinidin, and pelargonidin were detected in different color forms in A. arvensis. Ishikura (1981) identified malvidin 3-rhamnoside, luteolin, luteolin 7-glucoside, and quercetin 3 -rhamnoside in blue-flowered $A$. arvensis. Elsherif (2000) isolated the enzymes chalcone synthase and flavanone 3-hydroxylase from flowers of A. monelli 'Skylover Blue' and 'Sunrise' and reported finding only pelargonidin derivatives in flowers of 'Sunrise' and only malvidin derivatives in flowers of 'Skylover Blue'.

At UNH, hybridizations between the blue- and orange-flowered $A$. monelli cultivars Gentian Blue and Sunrise, respectively, produced progeny populations from which plants with a new red flower color were isolated (Freyre and Griesbach, 2004). Genetic and biochemical analyses were performed on 65 plants comprising a pooled set of four $\mathrm{F}_{2}$ populations derived by selfing and reciprocally mating two $F_{1}$ plants obtained from the cross 'Gentian Blue' $\times$ 'Sunrise'. High-performance liquid chromatography (HPLC) confirmed that orange color is attributable primarily to pelargonidin, blue to malvidin, and red to delphinidin. A three-gene genetic model for flower color inheritance with an expected $\mathrm{F}_{2}$ generation segregation pattern of 52 orange: 9 blue: 3 red was proposed (Freyre and Griesbach, 2004).

The objective of this study was to further investigate the genetic basis for flower color variation in $A$. monelli, this time focusing on wild-collected germplasm of potential value to a breeding program. In this study, blueand orange-flowered diploid plants collected in the wild were hybridized to create several $\mathrm{F}_{2}$ populations, and color segregation ratios were analyzed. To better understand the biochemistry of flower color in this species, a sample of individuals with different tones for each flower color was analyzed for anthocyanidin content.

\section{Materials and Methods}

Development of plant populations. A collection of blue wild diploid accessions of A. monelli from Spain (individuals denoted here with code B) and orange wild diploid accessions from Italy (individuals denoted with code $\mathrm{O}$ ) was established at UNH in Apr. 2002. Plants were maintained at UNH research greenhouses under standard cultural conditions as previously described (Freyre and Griesbach, 2004) and propagated vegetatively by tip cuttings as needed. During July 2002, hybridizations were performed between blue- and orange-flowered plants to obtain $\mathrm{F}_{1}$ individuals. In early morning, buds were crosspollinated by hand and labeled 
with plastic color ties. Seeds were harvested from fruits that were totally mature and dry. In Feb. 2003, seeds were sown in plastic seed trays and placed under intermittent mist. When seedlings started to germinate, trays were moved from the mist onto a greenhouse bench. Seedlings were initially transplanted into small cell packs and later into $15-\mathrm{cm}$ pots.

Self-incompatibility in $\mathrm{F}_{1}$ individuals was confirmed by their lack of fruit formation after manual self-pollinations or when individually maintained in cages for isolation. Thus, between July and Sept. 2003, hybridizations were performed between $\mathrm{F}_{1}$ siblings and between nonrelated progeny plants in all possible combinations to obtain second-generation populations. All second-generation seed obtained was sown in Dec. 2003.

Flower color determination. Flower color was determined by visual observation as soon as $F_{1}$ and second-generation plants started to bloom. For second-generation individuals chosen for biochemical analysis, flower color was also determined with the Munsell Color Chart (Nickerson, 1947) in freshly opened flowers under indirect sunlight. This chart was used because it is more accurate and informative than the Royal Horticultural Society Color Chart for determination of different tones of the same color, because it evaluates the flower color based on different attributes (hue, value, and chroma) so that color differences may be noted more specifically (Griesbach and Austin, 2005a). A color code was determined for each individual as a three-value code (e.g., 8.3 PB 3.2/16.0). The first number and letters refer to the "hue", which is the tone itself, the second number refers to the "value", which is how much white or black is in the color, and the third number stands for the "chrome", which defines color intensity.

High-performance liquid chromatography analysis. Analyses of anthocyanidin contents were performed on parental and $F_{1}$ individuals. In the $F_{2}$ populations, a sample of individuals was selected for each flower color, aiming to capture the variation of tones in each color. Fresh flowers were ground in $1 \%(\mathrm{v} / \mathrm{v}) \mathrm{HCl}$ in methanol. The extract was filtered and reduced to dryness under reduced pressure at $40{ }^{\circ} \mathrm{C}$. The residue was dissolved in $1 \%(\mathrm{v} / \mathrm{v}) \mathrm{HCl}$ in methanol and clarified by centrifugation at $100,000 \times g$ for $2 \mathrm{~min}$.

The anthocyanins were characterized by HPLC as previously described (Griesbach et al., 1991) using a $7.8 \times 300-\mathrm{mm}$ column of $5 \mu \mathrm{m}$ Bondapak $\mathrm{C} 18$ with a 30 -min linear gradient of $0 \%$ to $10 \%(\mathrm{v} / \mathrm{v})$ acetonitrile in aqueous $1.5 \%(\mathrm{v} / \mathrm{v})$ phosphoric acid and $15 \%$ $(\mathrm{v} / \mathrm{v})$ acetic acid followed by a 10-min linear increase to $20 \%(\mathrm{v} / \mathrm{v})$ acetonitrile and finally held at $20 \%(\mathrm{v} / \mathrm{v})$ acetonitrile for an additional $10 \mathrm{~min}$. Flow rate was $1.0 \mathrm{~mL} \cdot \mathrm{min}^{-1}$ and detection was by absorption at $540 \mathrm{~nm}$.

Individual anthocyanin peaks were collected and acid hydrolyzed at $100{ }^{\circ} \mathrm{C}$ in $3 \mathrm{~N}$ $\mathrm{HCl}$ for $1 \mathrm{~h}$. The hydrolyzed anthocyanidin products were characterized by HPLC as previously described (Griesbach et al.,
1991) using a $7.8 \times 300-\mathrm{mm}$ column of $5 \mu \mathrm{m}$ Bondapak C18 with a 20-min linear gradient of $0 \%$ to $15 \%(\mathrm{v} / \mathrm{v})$ acetonitrile in aqueous $1.5 \%(\mathrm{v} / \mathrm{v})$ phosphoric acid and $15 \%(\mathrm{v} / \mathrm{v})$ acetic acid and held at $15 \%(\mathrm{v} / \mathrm{v})$ for an additional $20 \mathrm{~min}$. Flow rate was $1.0 \mathrm{~mL} \cdot \mathrm{min}^{-1}$ and detection was by absorption at $540 \mathrm{~nm}$. Anthocyanidins were characterized by coelution with known standards and by comparative ultraviolet spectrophotometry with known standards (Harborne, 1968).

Statistical analysis. Flower color segregation ratios in second-generation progenies were evaluated by $\chi^{2}$ analysis for goodness of fit to ratios based on the previously proposed three-gene genetic model (Freyre and Griesbach, 2004) and to an expanded, fourgene model.

\section{Results and Discussion}

$F_{1}$ populations. Flower production in parental individuals was variable; thus, the number of hybridizations performed for each combination of blue and orange parents varied from one to 11 . The number of hybridizations performed, number of fruits harvested, and $F_{1}$ individuals obtained are presented in Table 1. Not all hybridizations were successful, and fruiting success ranged from $0 \%$ to $100 \%$. This may indicate that reproductive barriers exist between these allopatric wild populations. Interestingly, in some cases, hybridizations failed in one direction (e.g., $\mathrm{B} 1 \times \mathrm{O} 3$ ), whereas the reciprocal was successful.

All available seed from 16 different crosses were sown but very few $\mathrm{F}_{1}$ progeny were obtained. Initially, $15 \mathrm{~F}_{1}$ individuals were obtained but four of them died soon after germination, resulting in $11 \mathrm{~F}_{1}$ individ- uals from six different crosses. All $11 \mathrm{~F}_{1}$ individuals had orange flowers.

Although more fruits were obtained from orange $\times$ blue $(25)$ than from blue $\times$ orange crosses (17), the crosses in which the seed parent was blue-flowered were more successful in recovery of viable $F_{1}$ hybrids. Only one of 13 different orange $\times$ blue crosses produced one viable $\mathrm{F}_{1}$ individual $[\mathrm{O} 4 \times \mathrm{B} 1$ $\left.\left(\mathrm{F}_{1} \mathrm{~F}\right)\right]$, whereas 10 different $\mathrm{F}_{1}$ individuals were obtained from blue $\times$ orange crosses (Fig. 1). Three crosses, $\mathrm{B} 2 \times \mathrm{O} 5\left(\mathrm{~F}_{1} \mathrm{D}\right), \mathrm{B} 4 \times$ $\mathrm{O} 6\left(\mathrm{~F}_{1} \mathrm{E}\right)$, and $\mathrm{O} 4 \times \mathrm{B} 1\left(\mathrm{~F}_{1} \mathrm{~F}\right)$, had only one $\mathrm{F}_{1}$ individual. The cross $\mathrm{B} 2 \times \mathrm{O} 4$ resulted in three $F_{1}$ individuals, coded $F_{1} A_{1}, F_{1} A_{2}$, and $F_{1} A_{3}$. Similarly, cross $B 3 \times O 1$ had three $F_{1}$ individuals, coded $\mathrm{F}_{1} \mathrm{~B}_{1}, \mathrm{~F}_{1} \mathrm{~B}_{2}$, and $\mathrm{F}_{1} \mathrm{~B}_{3}$. Cross $\mathrm{B} 4 \times \mathrm{O} 4$ had two $\mathrm{F}_{1}$ individuals, coded $\mathrm{F}_{1} \mathrm{C}_{1}$ and $\mathrm{F}_{1} \mathrm{C}_{2}$. Wild orange-flowered individuals of $A$. monelli from Italy had an average flower diameter of $2.2 \mathrm{~cm}$, whereas blue-flowered individuals from Spain averaged $1.8 \mathrm{~cm} . \mathrm{F}_{1}$ plants showed hybrid vigor evidenced by larger flowers averaging $2.5 \mathrm{~cm}$ in diameter as well as stronger stems and more robust growth than their wild parents.

Second-generation populations. Twenty self-pollinations were performed on each of the $11 \mathrm{~F}_{1}$ hybrids, and no fruits were formed. In addition, these $F_{1}$ individuals were vegetatively propagated and one replicate plant for each individual was maintained in isolation inside a mesh cage in the greenhouse. Over 1500 flowers were produced per plant during a period of 3 months with no fruit formation. These results are consistent with the presence of self-incompatibility as reported in blue-flowered accessions from Spain (Talavera et al., 2001). To obtain a second generation, 20 hybridizations were performed between siblings in each of $F_{1} A$, $\mathrm{F}_{1} \mathrm{~B}$, and $\mathrm{F}_{1} \mathrm{C}$ populations in all possible combinations. Because it was unknown

Table 1. Crosses performed between orange- and blue-flowered wild individuals of $A$. monelli to obtain $\mathrm{F}_{1}$ populations ${ }^{\mathrm{z}}$.

\begin{tabular}{|c|c|c|c|c|c|c|}
\hline Seed parent & $\begin{array}{l}\text { Pollen } \\
\text { parent }\end{array}$ & No. crosses & No. fruits & $\begin{array}{c}\text { Fruiting } \\
\text { success }(\%)\end{array}$ & $\mathrm{F}_{1}$ progeny & $\mathrm{F}_{1}$ code \\
\hline$\overline{\mathrm{B} 1}$ & $\mathrm{O} 3$ & 2 & 0 & 0 & 0 & \\
\hline B1 & O4 & 3 & 0 & 0 & 0 & \\
\hline B2 & O4 & 2 & 2 & 100 & 3 & $\mathrm{~F}_{1} \mathrm{~A}$ \\
\hline B2 & O5 & 4 & 4 & 100 & 1 & $\mathrm{~F}_{1} \mathrm{D}$ \\
\hline B3 & $\mathrm{O} 1$ & 4 & 2 & 50 & 4 (1 died) & $\mathrm{F}_{1} \mathrm{~B}$ \\
\hline B4 & O4 & 10 & 4 & 40 & 5 (3 died $)$ & $\mathrm{F}_{1} \mathrm{C}$ \\
\hline B4 & O6 & 11 & 5 & 45.5 & 1 & $\mathrm{~F}_{1} \mathrm{E}$ \\
\hline Total & & 36 & 17 & & 10 & \\
\hline $\mathrm{O} 1$ & B1 & 4 & 2 & 50 & 0 & \\
\hline O1 & B3 & 4 & 4 & 100 & 0 & \\
\hline $\mathrm{O} 2$ & B1 & 4 & 2 & 50 & 0 & \\
\hline $\mathrm{O} 2$ & B2 & 1 & 0 & 0 & 0 & \\
\hline $\mathrm{O} 2$ & B3 & 1 & 0 & 0 & 0 & \\
\hline $\mathrm{O} 3$ & B5 & 3 & 3 & 100 & 0 & \\
\hline $\mathrm{O} 3$ & B1 & 3 & 2 & 66.7 & 0 & \\
\hline $\mathrm{O} 3$ & B2 & 3 & 1 & 33.3 & 0 & \\
\hline $\mathrm{O} 3$ & B3 & 3 & 3 & 100 & 0 & \\
\hline O4 & B1 & 2 & 2 & 100 & 1 & $\mathrm{~F}_{1} \mathrm{~F}$ \\
\hline O4 & B2 & 3 & 2 & 66.7 & 0 & \\
\hline O5 & B1 & 3 & 3 & 100 & 0 & \\
\hline O5 & B2 & 4 & 1 & 25 & 0 & \\
\hline Total & & 38 & 25 & & 1 & \\
\hline
\end{tabular}

Number of crosses, number of fruits, and number of seedlings per cross are included. Letters in the code of the individuals refer to the flower color: $\mathrm{O}$ for orange-flowered plants and $\mathrm{B}$ for blue-flowered plants. 
whether these hybridizations would be compatible, five to 10 hybridizations between individuals from different $F_{1}$ populations were also performed.

A total of 28 different crossing combinations between $\mathrm{F}_{1}$ individuals were performed. For crosses between unrelated $\mathrm{F}_{1}$ plants, fruiting success ranged from $16.6 \%$ to $100 \%$ with an average of $61.9 \%$ (data not shown). Seven crossing combinations and their reciprocals were performed between $\mathrm{F}_{1}$ siblings, and fruits were produced in only six combinations $\left(\mathrm{F}_{1} \mathrm{~A}_{1} \times \mathrm{F}_{1} \mathrm{~A}_{2}\right.$ and its reciprocal; $\mathrm{F}_{1} \mathrm{~A}_{2} \times \mathrm{F}_{1} \mathrm{~A}_{3}$ and its reciprocal; $\mathrm{F}_{1} \mathrm{C}_{1} \times \mathrm{F}_{1} \mathrm{C}_{2}$ and its reciprocal; Table 2). For these combinations, fruiting success ranged from $55 \%$ to $90 \%$. Crosses between siblings that failed to produce any fruit could be the result of gametophytic self-incompatibility as previously described (Talavera et al., 2001).

Fruits were harvested over a period of 3 months. All seed were initially dried with silica gel for $3 \mathrm{~d}$ and then stored. To have a better understanding of germination rates in this plant material, seeds per fruit were counted. A taxonomical description of $A$. monelli states that fruits contain 20 to 45 seeds (Tutin et al., 1972). Studies on blueflowered wild individuals of $A$. monelli report 20 to 30 seeds per fruit (Gibbs and Talavera, 2001); however, in diallel crosses, some fruits were found to contain only one to two seeds explained as the rare consequence of a few pollen tubes crossing the self-incompatibility "barrier" in the style (Talavera et al., 2001).
In this study, the number of seeds per fruit in crosses between siblings ranged from 8.5 to 16.7 with an average of 14.1. For crosses between unrelated $F_{1}$ individuals, the number of seed ranged from nine to 24.7 with an average of 15.4 (data not shown). Again, this low seed number may be explained by reproductive barriers between the two populations, suggesting that these populations are genetically divergent.

Ten days after the final seed count, all $\mathrm{F}_{2}$ seed was sown. Seed germination time was very uneven, ranging between 8 to $51 \mathrm{~d}$. Although the erratic germination could be a characteristic of the species, it may have been influenced by different harvest dates and storage periods. Germination rates in the $\mathrm{F}_{2}$ populations were very low ranging from zero to only $33.3 \%$. In the six $\mathrm{F}_{2}$ populations obtained from crosses between siblings, germination rates ranged from $16.8 \%$ to $30.7 \%$ (Table 2). One explanation for low germination rates is that capsules were harvested before they naturally dehisced to prevent losing seeds, and seed may not have been completely mature. Other factors may have been presence of dormancy or unviable embryos; however, in such small seed (size of a poppy seed), it is impossible to assess embryo viability. Our low germination rates agree with previous studies on natural populations of blue-flowered $A$. monelli explained by low female fecundity resulting from "male-dominant" (impaired female fertility) individuals (Gibbs and Talavera, 2001).
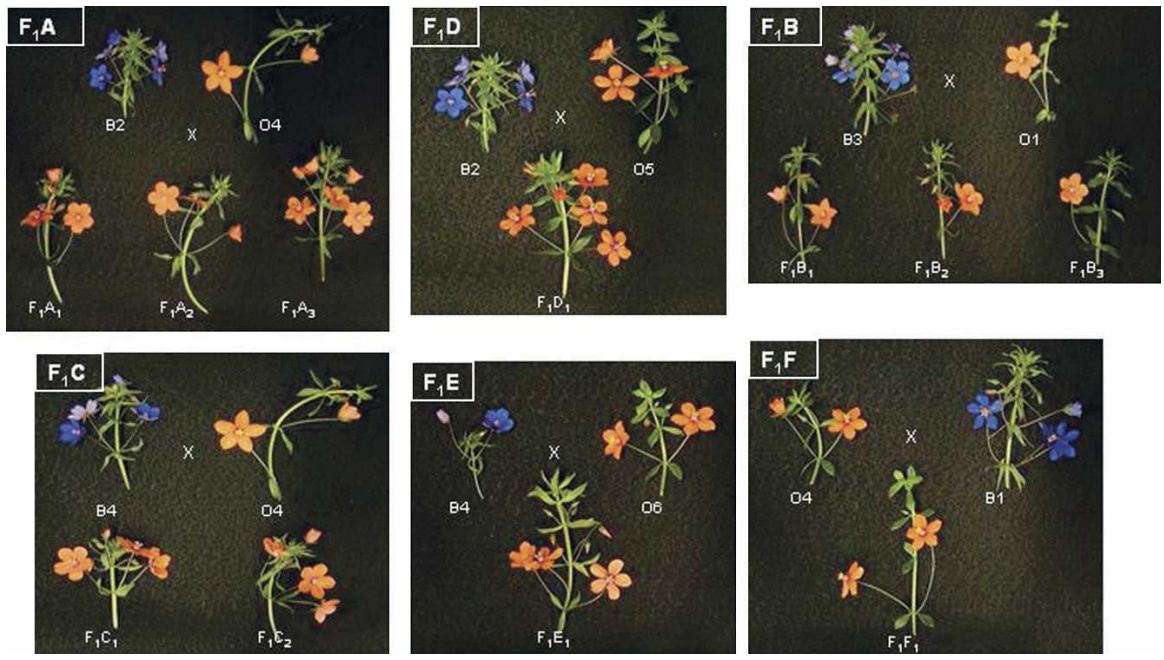

Fig. 1. Parents and $\mathrm{F}_{1}$ individuals of crosses between orange- and blue-flowered wild Anagallis monelli. In each individual picture, seed parent (top left), pollen parent (top right), progeny (second row).
Flower color segregation. Six $\mathrm{F}_{2}$ populations obtained from crosses between siblings and their respective reciprocals $\left[\mathrm{F}_{2} 1, \mathrm{~F}_{2} 1(\mathrm{R})\right.$, $\mathrm{F}_{2} 2, \mathrm{~F}_{2} 2(\mathrm{R}), \mathrm{F}_{2} 7$ and $\left.\mathrm{F}_{2} 7(\mathrm{R})\right]$ were selected for segregation analysis, whereas progenies obtained from crosses between unrelated individuals were not used. Because of the problems with fertility, limited numbers of $\mathrm{F}_{2}$ seedlings could be obtained, but population sizes were sufficient to permit testing of observed results to ratios expected on the basis of relevant genetic models (Table 3 ). Orange-, blue-, and red-flowered segregants were represented in all six populations. Surprisingly, the $\mathrm{F}_{2} 2$ and $\mathrm{F}_{2} 2(\mathrm{R})$ populations also contained white-flowered segregants. This flower color is nonexistent in natural populations, as far as we are aware. The $\mathrm{F}_{2} 2$ and $\mathrm{F}_{2} 2(\mathrm{R})$ populations fit a 3 pigmented:1 unpigmented monohybrid segregation ratio $\left(\chi^{2}=1.87, P=0.17\right.$ and $\chi^{2}=0.16, P=0.69$, respectively, data not shown), suggesting that white flower color was the result of homozygosity for a single, recessive gene, "d", in these populations. The parental source of the " $d$ " allele cannot be deduced from the available information. The presence of whiteflowered individuals suggests an upstream mutation in the anthocyanin pathway, resulting in a colorless product (Fig. 2). This mutation may have been carried by one of the parents of family $\mathrm{F}_{1} \mathrm{~A}, \mathrm{~B} 2$, or $\mathrm{O} 4$ in which case, $F_{1}$ individuals segregating genotypes would be heterozygous $\left(\mathrm{F}_{1} \mathrm{~A}_{2}\right.$ and $\left.\mathrm{F}_{1} \mathrm{~A}_{3}\right)$ or dominant homozygous $\left(\mathrm{F}_{1} \mathrm{~A}_{1}\right)$ for the recessive mutation.

In the genetic model for flower color inheritance previously proposed for A. monelli (Fig. 2), genotypes $A$---- and -- $b b$-- have orange flowers (as a result of pelargonidin), $a a B-C$ - have blue flowers (as a result of malvidin) and $a a B-c c$ have red flowers (as a result of delphinidin) (Freyre and Griesbach, 2004). Under this model, 21 different genotypes specify orange, four specify blue, and two specify red. The respective epistatic interactions are somewhat complex such that the A locus has influence only in the presence of genotype "B---", the B locus has influence only in the presence of the genotype "aa--", and the $\mathrm{C}$ locus has influence only in the presence of the genotype "aaB-". Given that parental source populations were monomorphic for their respective blue (Spain) and orange (Italy) flower colors, and that red flower color has not been reported in either of the source populations but did occur in all of the $\mathrm{F}_{2}$ populations studied here, inferences can be drawn as to source population and parental genotypes.

Table 2. Successful crosses between $\mathrm{F}_{1}$ siblings in $A$. monelli that produced $\mathrm{F}_{2}$ populations.

\begin{tabular}{|c|c|c|c|c|c|c|c|c|}
\hline $\mathrm{F}_{2}$ & Cross description & $\begin{array}{c}\text { No. } \\
\text { crosses }\end{array}$ & $\begin{array}{l}\text { No. } \\
\text { fruits }\end{array}$ & $\begin{array}{c}\text { Fruiting } \\
\text { success }(\%)\end{array}$ & $\begin{array}{l}\text { No. } \\
\text { seeds }\end{array}$ & $\begin{array}{l}\text { Avg. no. } \\
\text { seeds/fruit }\end{array}$ & $\begin{array}{c}\text { No. } \\
\mathrm{F}_{2} \text { progeny }\end{array}$ & $\begin{array}{c}\text { Percent } \\
\text { germination }\end{array}$ \\
\hline$\overline{F_{2} 1}$ & $\mathrm{~F}_{1} \mathrm{~A}_{1} \times \mathrm{F}_{1} \mathrm{~A}_{2}$ & 20 & 18 & 90 & 276 & 15.3 & 70 & 25.4 \\
\hline $\mathrm{F}_{2} 1(\mathrm{R})$ & $\mathrm{F}_{1} \mathrm{~A}_{2} \times \mathrm{F}_{1} \mathrm{~A}_{1}$ & 20 & 11 & 55 & 176 & 16.0 & 54 & 30.7 \\
\hline $\mathrm{F}_{2} 2$ & $\mathrm{~F}_{1} \mathrm{~A}_{2} \times \mathrm{F}_{1} \mathrm{~A}_{3}$ & 20 & 16 & 80 & 241 & 15.1 & 60 & 24.9 \\
\hline $\mathrm{F}_{2} 2(\mathrm{R})$ & $\mathrm{F}_{1} \mathrm{~A}_{3} \times \mathrm{F}_{1} \mathrm{~A}_{2}$ & 20 & 13 & 65 & 110 & 8.5 & 19 & 17.3 \\
\hline $\mathrm{F}_{2} 7$ & $\mathrm{~F}_{1} \mathrm{C}_{1} \times \mathrm{F}_{1} \mathrm{C}_{2}$ & 20 & 15 & 75 & 250 & 16.7 & 42 & 16.8 \\
\hline $\mathrm{F}_{2} 7(\mathrm{R})$ & $\mathrm{F}_{1} \mathrm{C}_{2} \times \mathrm{F}_{1} \mathrm{C}_{1}$ & 20 & 12 & 60 & 145 & 12.1 & 43 & 29.7 \\
\hline
\end{tabular}


Table 3. $\chi^{2}$ goodness of fit test for flower color segregation ratios in $\mathrm{F}_{2}$ populations of $A$. monelli.

\begin{tabular}{|c|c|c|c|c|c|c|c|c|c|c|}
\hline \multirow[b]{2}{*}{ Family } & \multirow{2}{*}{$\frac{\text { Expected }}{\text { segregation ratios }^{2}}$} & & \multirow[b]{2}{*}{ Orange } & \multicolumn{3}{|c|}{ Flower color } & \multirow[b]{2}{*}{ Total } & \multirow[b]{2}{*}{$\chi^{2}$} & \multirow[b]{2}{*}{$\mathrm{df}$} & \multirow[b]{2}{*}{$P$} \\
\hline & & & & Blue & Red & White & & & & \\
\hline \multirow{2}{*}{$\overline{\mathrm{F}_{2} 1}$} & $52: 9: 3$ & Expected & 52 & 9 & 3 & & 64 & 22.88 & 2 & 0.00001075 \\
\hline & $48: 12: 4$ & Expected & 48 & 12 & 4 & & 64 & 10.4 & 2 & 0.995 \\
\hline \multirow{2}{*}{$\mathrm{F}_{2} 1(\mathrm{R})$} & $52: 9: 3$ & Expected & 39 & 6.75 & 2.25 & & 48 & 3.84 & 2 & 0.15 \\
\hline & $48: 12: 4$ & Expected & 36 & 9 & 3 & & 48 & 3.2 & 2 & 0.8 \\
\hline $\mathrm{F}_{2} 7$ & & Observed & 29 & 11 & 2 & & 42 & & & \\
\hline \multirow[t]{3}{*}{$\mathrm{F}_{2} 7(\mathrm{R})$} & & Observed & 33 & 6 & 1 & & 40 & & & \\
\hline & $52: 9: 3$ & Expected & 32.5 & 5.63 & 1.88 & & 40 & 0.44 & 2 & 0.81 \\
\hline & $48: 12: 4$ & Expected & 30 & 7.5 & 2.5 & & 40 & 1.5 & 2 & 0.53 \\
\hline \multirow{2}{*}{$\mathrm{F}_{2} 2$} & & Observed & 31 & 6 & 2 & 19 & 58 & & & \\
\hline & $156: 27: 9: 64$ & Expected & 35.3 & 6.1 & 2.1 & 14.5 & 58 & 1.93 & 3 & 0.59 \\
\hline \multirow[t]{2}{*}{$\mathrm{F}_{2} 2(\mathrm{R})$} & & Observed & 8 & 6 & 1 & 4 & 19 & & & \\
\hline & $156: 27: 9: 64$ & Expected & 11.6 & 2 & 0.65 & 4.75 & 19 & 9.42 & 3 & 0.02 \\
\hline
\end{tabular}

${ }^{\mathrm{z}}$ Expected segregation ratio for a three-gene genetic model (52:9:3), a three-gene genetic model (48:12:4), or for a four-gene genetic model (156:27:9:64).
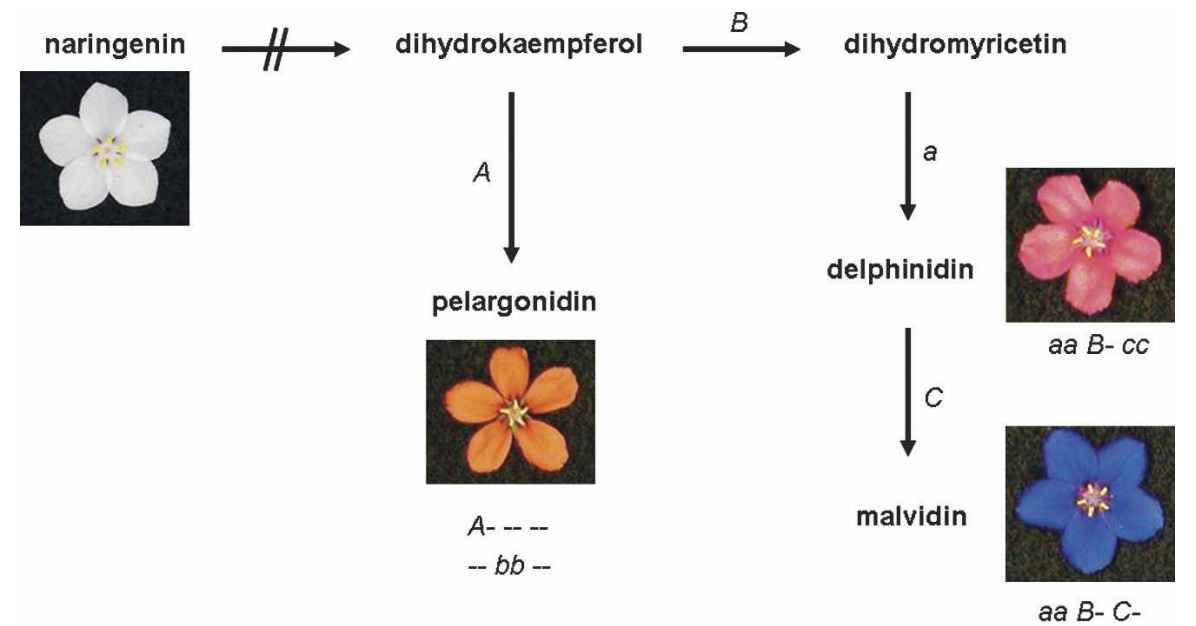

Fig. 2. Proposed four-gene model for the inheritance of flower color in Anagallis monelli. Genotypes and loci are indicated in italics. Anthocyanidins detected in this species are pelargonidin, delphinidin, and malvidin, which are primarily responsible for orange, red, and blue flowers, respectively. It is hypothesized white flower color results from an upstream mutation in the metabolic pathway.

The Spain population is observationally monomorphic for blue flower color. To be such, this source population can be inferred to harbor no "A" alleles (which would confer orange flower color), no "b" alleles (which would confer orange flower color in homozygous form), and no "c" alleles (which would confer red flower color in the homozygous form in the presence of aaB). As such, the Spain population must be monomorphic for the genotype aaBBCC, and blue-flowered parent plants, B2 and B4, must both have this genotype.

By extension from the foregoing reasoning, either the Italy population must be the source of the "c" allele or the "c" allele must have arisen de novo in parental plant O4. To segregate in all six $\mathrm{F}_{2}$ populations, the "c" allele must have been transmitted to all five $F_{1}$ plants used in the $F_{1}$ intercrosses, so it is most likely $\left\{\left[P=1-(0.5)^{5}\right]>0.94\right\}$ that parental plant $\mathrm{O} 4$ was homozygous for the "c" allele. This finding, along with the prior occurrence of red-flowered plants in progenies of crosses between 'Sunrise' and 'Gentian Blue' (Freyre and Griesbach, 2004), argues against a de novo mutational source for the "c" allele. However, if the "c" allele was present in the Italy source population, then the absence of red-flowered (aaB-cc) plants in the Italy population implies that this population must have lacked either the "a" allele (thereby excluding the "aa" genotype), the "B" allele (thereby excluding the Bgenotype), or both (thereby excluding the aaB- genotype). On the basis of this, the inferred genotype possibilities for plant $\mathrm{O} 4$ are AAbbcc, Aabbcc, and AABbcc. However, the Aabbcc possibility can be excluded, because the cross Aabbcc (orange) $\times$ aaBBCC (blue) would be expected to produce a $1: 1$ ratio of orange $(\mathrm{AaBbCc})$ and blue (aaBbCc) $\mathrm{F}_{1}$ plants, but all $11 \mathrm{~F}_{1}$ plants had orange flowers. On this basis, and given the putative aaBBCC genotype of blue-flowered parents $\mathrm{B} 2$ and $\mathrm{B} 4$, all 11 orange-flowered $\mathrm{F}_{1}$ plants had one of two possible genotypes: $\mathrm{AaBbCc}$ or $\mathrm{AaBBCc}$. Accordingly, the $\mathrm{F}_{2}$ populations could be expected to segregate in one of two possible ratios depending on the combination of $F_{1}$ genotypes in the $F_{1}$ intercross: $\mathrm{AaBbCc} \times \mathrm{AaBbCc}$ would yield the previously modeled trihybrid ratio of 52 orange: 9 blue: 3 red, whereas $\mathrm{AaBbCc} \times$ $\mathrm{AaBBCc}$ and $\mathrm{AaBBCc} \times \mathrm{AaBBCc}$ would each yield an expectation of 48 orange: 12 blue: 4 red.

With respect to the expected three-class color segregation pattern, populations $\mathrm{F}_{2} 1(\mathrm{R})$ ( $P=0.15$ and $P=0.8$, respectively), $\mathrm{F}_{2} 7$ ( $P=0.09$ and $P=0.55$, respectively $)$, and $\mathrm{F}_{2} 7(\mathrm{R})(P=0.81$ and $P=0.53$, respectively) did not differ significantly from the modeled 52:9:3 and 48:12:4. Additionally, population $\mathrm{F}_{2} 1 \quad(P=0.99)$ did not differ significantly from the modeled 48:12:4. These data permit the inference that the genotypes of the $F_{1}$ plants $\left(F_{1} A_{1}, F_{1} A_{2}\right.$, $\mathrm{F}_{1} \mathrm{C}_{1}$, and $\mathrm{F}_{1} \mathrm{C}_{2}$ ) that were variously intermated (Table 2) to produce these $\mathrm{F}_{2}$ populations were $\mathrm{AaB}-\mathrm{Cc}$.

For the two populations in which white flower color appeared, we tested a four-gene model with the expected segregation ratio 156 orange: 27 blue:9 red:64 white. Segregation of $\mathrm{F}_{2} 2$ did not differ significantly from the model with $\chi^{2}=1.93, P=0.59$ (Table 3 ). Reciprocal population $F_{2} 2(\mathrm{R})$ did not fit the indicated ratio, but this data set was considered too small $(\mathrm{n}=19)$ to provide a meaningful test of a four-class expected ratio.

Overall, with the exception of family $F_{2} 1$, the predictions of the three- and four-gene models used here provided a reasonable fit to the observed segregation patterns. Statistically significant or nonsignificant deviations from the expected ratios may be attributable to a variety of factors. As one possibility, such deviations could reflect segregation distortion resulting from genetic linkages between anthocyanin pathway genes and loci that are the subject of gametophytic or sporophytic selection. This hypothesis is consistent with the generally low and inconsistent seed germination rates observed here. The distortion of Mendelian ratios in crosses involving wild-collected parental plants has been widely reported in many taxa, including Fragaria (Yu and Davis, 1995), Mimulus (Hall and Willis, 2005), and Oryza (Li et al., 1997). Distortion 
that occurs in only one direction of the cross, as seen in Fragaria (Davis and Yu, 1997) and here in family $F_{2} 1$ but not in $F_{2} 1(R)$, may be attributable to differential interactions between uniparentally inherited cytoplasmic genomes and biparentally inherited nuclear alleles.

As another possibility, such deviations could be the result of the color classification methodology. We previously reported (Freyre and Griesbach, 2004) that flowers that appeared orange could contain more than $50 \%$ malvidin and less than $44 \%$ pelargonidin. Further studies were undertaken to analyze pigment composition of segregants within the $\mathrm{F}_{2}$ populations.

High-performance liquid chromatography analysis. For selected families $\mathrm{F}_{2} 1, \mathrm{~F}_{2} 2$, and $\mathrm{F}_{2} 7$, flower color of seed and pollen parents, $F_{1}$ individuals, and a total of $19 F_{2}$ individuals were determined more precisely using Munsell color codes. Additionally, anthocyanidin contents were analyzed with HPLC. Three white individuals were analyzed for anthocyanidin contents, and none were detected. For the $\mathrm{F}_{2} \mathrm{~s}$, individuals in different shades for each color (orange, blue, and red) were selected aiming to capture the biggest range of color variability. As was expected from the previous study, three anthocyanidins were found to determine flower color in this species, pelargonidin being primarily responsible for orange flower color, delphinidin for red, and malvidin for blue (Freyre and Griesbach, 2004). However, our results indicate that individuals of the same color class can have varying combinations of these three pigments (Table 4).

Table 4. Munsell color code, and anthocyanidin contents of parents, $\mathrm{F}_{1}$, and $\mathrm{F}_{2}$ individuals of $A$. monelli selected for biochemical analysis.

\begin{tabular}{|c|c|c|c|c|}
\hline \multirow[b]{2}{*}{ Plant } & \multirow[b]{2}{*}{ Color } & \multicolumn{3}{|c|}{ Anthocyanidin } \\
\hline & & Pelargonidin & Delphinidin & Malvidin \\
\hline $\mathrm{O} 4$ (orange parent) & 0.1 YR $6.4 / 14.3$ & 89.9 & 6 & 4.1 \\
\hline B2 (blue parent) & 8.3 PB 3.2/16.0 & 11.2 & 0.4 & 88.4 \\
\hline B4 (blue parent) & 7.4 PB 2.8/16.4 & 0 & 0 & 100 \\
\hline $\mathrm{F}_{1} \mathrm{~A}_{1}^{\mathrm{z}}$ & 0.1 YR $6.7 / 14.0$ & 87.2 & 0 & 12.8 \\
\hline $\mathrm{F}_{1} \mathrm{~A}_{2}{ }^{\mathrm{z}}$ & 0.1 YR $6.4 / 15.0$ & 78.4 & 5.7 & 15.9 \\
\hline $\mathrm{F}_{1} \mathrm{~A}_{3}{ }^{\mathrm{z}}$ & 0.5 YR $6.4 / 15.0$ & 88.7 & 0.2 & 11.1 \\
\hline $\mathrm{F}_{1} \mathrm{C}_{1}^{\mathrm{y}}$ & 9.7 R 6.7/11.9 & 27.7 & 47 & 25.3 \\
\hline $\mathrm{F}_{1} \mathrm{C}_{2}^{\mathrm{y}}$ & 0.1 YR $6.7 / 13.5$ & 29.4 & 56 & 14.6 \\
\hline $\mathrm{F}_{2} 1$ (orange 1 ) & 0.1 YR 6.4/14.3 & 94.8 & 3.2 & 2 \\
\hline $\mathrm{F}_{2} 1(\mathrm{R})$ (orange 2) & 9.0 R 6.1/14.0 & 87.6 & 1.1 & 11.3 \\
\hline $\mathrm{F}_{2} 2$ (orange 3 ) & 0.1 YR $6.4 / 14.3$ & 32.9 & 66.7 & 0.4 \\
\hline $\mathrm{F}_{2} 2($ orange 4$)$ & 0.5 YR $6.2 / 15.9$ & 97.9 & 2.1 & 0 \\
\hline $\mathrm{F}_{2} 7(\mathrm{R})$ (orange 5) & 9.0 R 5.9/15.8 & 89.7 & 1.2 & 9.1 \\
\hline $\mathrm{F}_{2} 1$ (blue 1 ) & 1.4 P $4.5 / 13.3$ & 1 & 0.9 & 98.1 \\
\hline $\mathrm{F}_{2} 1$ (blue 2) & 9.5 PB 4.4/13.0 & 0.1 & 0 & 99.9 \\
\hline $\mathrm{F}_{2} 1(\mathrm{R})$ (blue 3 ) & 8.3 PB 4.4/13.6 & 0 & 0.4 & 99.6 \\
\hline $\mathrm{F}_{2} 1(\mathrm{R})$ (blue 4) & 8.0 PB 5.6/10.5 & 0 & 2.6 & 97.4 \\
\hline $\mathrm{F}_{2} 2$ (blue 5) & 9.4 PB 4.0/14.9 & 0 & 3.3 & 96.7 \\
\hline$F_{2} 2(R)$ (blue 6) & 8.5 PB 4.0/15 & 1.1 & 1.1 & 97.8 \\
\hline $\mathrm{F}_{2} 2(\mathrm{R})$ (blue 7) & 8.3 PB 3.2/15.1 & 0 & 2.5 & 97.5 \\
\hline $\mathrm{F}_{2} 7$ (blue 8 ) & 9.5 PB 4.4/12.9 & 3.2 & 0 & 96.8 \\
\hline $\mathrm{F}_{2} 7$ (blue 9) & 9.8 P 5.1/17.2 & 0 & 0.6 & 99.4 \\
\hline $\mathrm{F}_{2} 7(\mathrm{R})$ (blue 10$)$ & 9.0 PB 3.3/15.4 & 0 & 0 & 100 \\
\hline $\mathrm{F}_{2} 1(\mathrm{red} 1)$ & 0.8 R $6.0 / 14.3$ & 0 & 95 & 5 \\
\hline $\mathrm{F}_{2} 1(\mathrm{R})(\mathrm{red} 2)$ & 9.4 RP $6.2 / 14.5$ & 0 & 100 & 0 \\
\hline $\mathrm{F}_{2} 2(\mathrm{R})(\operatorname{Red} 3)$ & 9.4 RP $6.2 / 14.5$ & 0 & 99.2 & 0.8 \\
\hline$F_{2} 7($ red 4$)$ & 3.5 R 5.1/16.6 & 0 & 100 & 0 \\
\hline
\end{tabular}

${ }^{\mathrm{z}} \mathrm{F}_{1} \mathrm{~A}_{1}, \mathrm{~F}_{1} \mathrm{~A}_{2}$, and $\mathrm{F}_{1} \mathrm{~A}_{3}$ are derived from a cross of $\mathrm{B} 2 \times \mathrm{O} 4$.

${ }^{y} \mathrm{~F}_{1} \mathrm{C}_{1}$ and $\mathrm{F}_{1} \mathrm{C}_{2}$ are derived from a cross of $\mathrm{B} 4 \times \mathrm{O} 4$.
The two wild blue accessions used as parents for the $F_{1}$ families in this study had slightly different flower colors (Table 4). The B4 parent was colored 7.4 PB 2.8/16.4 and contained exclusively malvidin, whereas the B2 parent was colored 8.3 PB 3.2/16 and contained mostly malvidin $(88.4 \%)$ with $11.2 \%$ pelargonidin and a trace of delphinidin. On the other hand, the orange parent $\mathrm{O} 4$ was colored 0.1 YR 6.4/14.3 and contained mostly pelargonidin $(89.9 \%)$ with small amounts of delphinidin $(6 \%)$ and malvidin $(4.1 \%)$.

The flower color of the $\mathrm{F}_{1}$ plants were all a shade of orange but varied in the pelargonidin concentration. One group of plants $\left(\mathrm{F}_{1} \mathrm{~A}_{1}\right.$, $\mathrm{F}_{1} \mathrm{~A}_{2}$, and $\mathrm{F}_{1} \mathrm{~A}_{3}$ ) contained mostly pelargonidin $(78 \%$ to $89 \%)$ with small amounts of malvidin (11\% to $16 \%)$ and delphinidin $(0 \%$ to $6 \%)$. The other group of plants $\left(\mathrm{F}_{1} \mathrm{C}_{1}\right.$ and $\mathrm{F}_{1} \mathrm{C}_{2}$ ) contained mostly delphinidin $(47 \%$ to $56 \%)$ with smaller amounts of pelargonidin (28\% to $29 \%)$ and malvidin $(15 \%$ to $25 \%)$. Both of these groups share the same orange-flowered parent $(\mathrm{O} 4)$ but have a different blue-flowered parent (B2 and $\mathrm{B} 4$ for families $\mathrm{F}_{1} \mathrm{~A}$ and $\mathrm{F}_{1} \mathrm{C}$, respectively). These results suggest that parents B2 and B4 differed in their genotypes at loci influencing flower color, including alleles or loci other than those specified by the used genetic model.

Variations in the shade of orange color also varied between $F_{2}$ plants. The flowers from four of five plants contained mostly pelargonidin $(88 \%$ to $95 \%)$ with small amounts of delphinidin ( $1 \%$ to $3 \%)$ and malvidin $(0 \%$ to $11 \%)$. On the other hand, the flowers from the fifth plant, $\mathrm{F}_{2} 2-$-Orange
3 , contained mostly delphinidin $(67 \%)$, pelargonidin (33\%), and a trace of malvidin. Another unusual orange-flowered plant was also reported by Freyre and Griesbach (2004) with mostly malvidin (50\%), slightly less pelargonidin (44\%), and a small amount of delphinidin (6\%). Results of the analyses for $\mathrm{F}_{1} \mathrm{~s}$ and $\mathrm{F}_{2} \mathrm{~s}$ indicate that even with amounts as low as $28 \%$ pelargonidin, the perceived color is orange.

For blue-flowered $\mathrm{F}_{2}$ plants, variations in shade were greater than those for orangeflowered plants. However, all blue-flowered plants contained predominantly malvidin (97\% to $100 \%)$. Freyre and Griesbach (2004) observed that only one of five blueflowered plants contained pelargonidin (4\%). In this study, of $10 \mathrm{~F} 2$ plants sampled, only one plant, $\mathrm{F}_{2} 7$-Blue 8 , contained a small amount of pelargonidin (3\%). Moreover, not all blue-flowered plants with the same anthocyanin profile were the same color. For example, both B4 and $\mathrm{F}_{2} 7(\mathrm{R})-\mathrm{Blue} 10$ contained 100\% malvidin and had 7.4 PB 2.8/ 16.4 and 9.0 PB 3.3/15.4 colored flowers, respectively.

For $\mathrm{F}_{2}$ red-flowered plants, variations in flower shade also occurred. However, as expected, in all cases flower color was the result of predominant delphinidin $(95 \%$ to $100 \%)$ with trace amounts of malvidin $(0 \%$ to $5 \%$ ). Similar to blue-flowered plants, not all red-flowered plants with the same anthocyanin profile had the same color. For example, both $\mathrm{F}_{2} 1(\mathrm{R})$-Red 2 and $\mathrm{F}_{2} 7$ - Red 4 contained $100 \%$ delphinidin but had 9.4 RP 6.2/14.5 and 3.5R 5.1/16.6 colored flowers, respectively. It is interesting that none of the red flowers contained any traces of pelargonidin. In this case, the enzyme's affinity to dihydromyricetin appears to be complete with no affinity to dihydrokaempferol. However, very low levels of pelargonidin were detected in $20 \%$ to $30 \%$ of the blue-flowered plants analyzed. Maybe if more red plants were sampled, some of them would have shown some traces of pelargonidin.

The simplest explanation for these observations is that multiple alleles at both the $B$ and $A$ loci compete for the same precursors. For example, both $A$ and $B$ compete for dihydrokaempferol. With an $A$ allele completely dominant over a $B$ allele, $100 \%$ pelargonidin would be produced. However, partially dominant alleles would result in a mixture of anthocyanidins. The two blueflowered parents that were used would be expected to have different but functional alleles at either the $A$ or $B$ locus. This is similar to the situation observed in Petunia in which nearly all the anthocyanin biosynthetic enzymes that have been studied will accept the different precursors as substrates (Griesbach, 1993; Huits et al., 1994). Detailed studies with microorganisms have resulted in mathematical models to predict the flow in biosynthetic pathways resulting from competing alleles (Keightley, 1989).

By analyzing a diverse range of individuals for each flower color, we have confirmed that multiple anthocyanidins can be found in 
the different color types, presumably as a result of affinity of enzymes to more than one substrate. In few of the plants studied, the perceived flower color did not match the expected genotype. For example, orangeflowered plants are expected to be either $A$ or $b b$ and to contain predominantly pelargonidin. However, at least one orange-flowered plant contained over $60 \%$ delphinidin $\left(\mathrm{F}_{2} 2\right.$ Orange 3).

Our results have also demonstrated that plants with the same anthocyanin profile were identified with different Munsell color codes. This is indicative that in addition to anthocyanidin contents, more factors are involved in determination of final flower color in A. monelli. One of the known factors affecting flower color is petal $\mathrm{pH}$ (Asen et al., 1977; Brouillard, 1988; Griesbach, 1996). However, using previous methods (Freyre and Griesbach, 2004), we determined that there was no difference in petal $\mathrm{pH}$ between the two groups of orange flowers (data not shown). Moreover, in another study, petal $\mathrm{pH}$ in blue, red, violet, and lilac flowers of $A$. monelli was not found to be significantly different (Quintana et al., 2007). Other factors that may be affecting flower color may include copigments, metal ions, or a different molecular conformation of the anthocyanin (Griesbach, 2005b).

\section{Conclusions}

The three-gene model previously proposed to explain the inheritance of flower color in $A$. monelli was expanded to include an additional gene to explain the new discovered white-flowered phenotype. Incomplete dominance of different alleles competing for the same precursor could explain the aberrant segregation patterns in some populations. Additionally, segregation distortion could be caused by linkages of anthocyanin genes to genetic factors influencing fertility, gametophyte, or embryo viability as is common is crosses involving wild, genetically diverged parents. The "c" allele that determines red flower color was inferred to be present only in the Italy source population. The new whiteflowered phenotype (with no anthocyanidins) was not significantly different from the expected ratios of a single gene model (pigmented versus white). We hypothesize that the white color is the result of an upstream mutation in the anthocyanin pathway, blocking the pathway before the production of colored anthocyanidins, resulting in a colorless product. This mutation would have originated from one of the wild parents.
Flower color in A. monelli is determined by a complex balance of anthocyanidin pigments. Pelargonidin is the main anthocyanidin responsible for orange flower color, delphinidin for red flower color, and malvidin for blue flower color. However, each of these pigments is not exclusively biosynthesized; all three of them may be present simultaneously, and their ratios determine flower color and different tones for each color. Other factors such as copigments, metal ions, or a different molecular conformation of the anthocyanin could also be involved in flower color determination in this species. Further testing of hypotheses about the genetic control of flower color variation in this species would be aided by the cloning of its anthocyanin pathway genes, providing opportunity to evaluate associations between specific candidate genes and particular flower color phenotypes.

\section{Literature Cited}

Asen, S., R.N. Stewart, and K.H. Norris. 1977. Anthocyanin and $\mathrm{pH}$ involved in the color of 'Heavenly Blue' Morning Glory. Phytochem. 16:1118-1119.

Brouillard, R. 1988. Flavonoids and flower color, p. 525-538. In: Harborne, J.B. (ed.). The flavonoids: Advances in research. Chapman \& Hall, London, UK.

Davis, T.M. and H. Yu. 1997. A linkage map of the diploid strawberry, Fragaria vesca. J. Hered. $88: 215-221$

Elsherif, T. 2000. Genetik und Enzymologie der Bildung außergerwöhlicher AnthocyanidinMuster in Blüten höherer Pflanzen. Munich Technical Univ., Munich, Germany. PhD Diss.

Freyre, R. and R.J. Griesbach. 2004. Inheritance of flower color in Anagallis monelli L. HortScience 39:1220-1223.

Gerats, A.G.M., P. de Vlaming, M. Doodeman, B. Al, and A.W. Schram. 1982. Genetic control of the conversion of dihydroflavonols into flavonols and anthocyanins in flowers of Petunia hybrida. Planta 155:364-368.

Gibbs, P.E. and S. Talavera. 2001. Breeding system studies with three species of Anagallis (Primulaceae): Self-incompatibility and reduced female fertility in A. monelli L. Ann. Bot. (Lond.) 88:139-144.

Griesbach, R.J. 1993. Characterization of the flavonoids from Petunia $\times$ hybrida flowers expressing the $A 1$ gene of Zea mays. HortScience 28:659-660.

Griesbach, R.J. 1996. The inheritance of flower color in Petunia hybrida Vilm. J. Hered. 87:241-245.

Griesbach, R.J., S. Asen, and B.A. Leonhard. 1991. Petunia hybrida anthocyanins acylated with caffeic acid. Phytochemistry 30:1729-1731.

Griesbach, R.J. and S. Austin. 2005a. Comparison of the Munsell and Royal Horticultural Soci- ety's Color Charts in describing flower color. Taxon 54:771-773.

Griesbach, R.J. 2005b. Genetics and biochemistry of flower color. Plant Breed. Rev. 25:89-114.

Hall, M.C. and J.H. Willis. 2005. Transmission ratio distortion in intraspecific hybrids of Mimulus guttatus: Implications for genomic divergence. Genetics 170:375-386.

Harborne, J.B. 1968. Comparative biochemistry of the flavonoids-VII. Correlations between flavonoid pigmentation and systematics in the family Primulaceae. Phytochemistry 7:1215-1230.

Holton, T.A. and E.C. Cornish. 1995. Genetics and biochemistry of anthocyanin biosynthesis. Plant Cell 7:1071-1083.

Huits, H.S.M., A.G.M. Gerats, M.M. Kreike, J.N.M. Mol, and R.E. Koes. 1994. Genetic control of dihydroflavonol 4-reductase gene expression in Petunia hybrida. Plant J. 6:295-310.

Ishikura, N. 1981. Flavonoid in petal cells of Anagallis arvensis f. coerulea containing a blue crystalline anthocyanin. Z. Pflanz. Bd. 103(Suppl):469-473.

Källersjö, M., G. Bergqvist, and A.A. Anderberg. 2000. Generic realignment in primuloid families of the Ericales s.1.: A phylogenetic analysis based on DNA sequences from three chloroplast genes and morphology. Amer. J. Bot. 87:1325-1341.

Keightley, P.D. 1989. Models of quantitative variation of flux in metabolic pathways. Genetics 121:869-876

Li, Z., S.R.M. Pinson, A.H. Paterson, W.D. Park, and J.W. Stansel. 1997. Genetics of hybrid sterility and hybrid breakdown in an intersubspecific rice (Oryza sativa L.) population. Genetics 145:1139-1148.

Nickerson, D. 1947. Interrelation of color specifications. Paper Trade J. 125:153-171.

Quintana, A., J. Albrechtova, R.J. Griesbach, and R. Freyre. 2007. Anatomical and biochemical studies of anthocyanidins in flowers of Anagallis monelli L. (Primulaceae) hybrids. Sci. Hort. 112:413-421.

Šveřepová, G. 1972. Zur zytotaxonomie der gattung Anagallis L. Preslia, Praha. 44:219-226.

Talavera, S., L. García Pérez, M. Arista, and P.L. Ortiz. 1997. Números cromosómicos de plantas occidentales. Anal. Jard. Bot. Madrid $55: 136$

Talavera, S., P.E. Gibbs, M.P. Fernández-Piedra, and M.A. Ortiz-Herrera. 2001. Genetic control of self-incompatibility in Anagallis monelli (Primulaceae: Myrsinaceae). Heredity 87 589-597.

Tutin, T.G., V.H. Heywood, N.A. Burges, D.M. Moore, D.H. Valentine, S.M. Walters, and D.A. Webb. 1972. Flora Europaea 3. Cambridge University Press, Cambridge, UK.

Valdés, B. 1970. Números cromosómicos de algunas plantas españolas. Bol. R. Soc. Española Hist. Nat. (Biol.) 68:193-197.

Yu, H.R. and T.M. Davis. 1995. Genetic linkage between runnering and Phosphoglucoisomerase allozymes, and systematic distortion of monogenic segregation ratios in diploid strawberry. JASHS 120:687-690. 